\title{
Toxicity of fluoxetine hydrochloride on some selected vital organs of pregnant mice Mus musculus
}

\author{
B.A. Mohammed ${ }^{1}\left(\mathbb{D}\right.$ and S.S. Al-Mahmood ${ }^{2}(\mathbb{D}$ \\ ${ }^{1}$ Department of Biology, College of Education for Pure Science, ${ }^{2}$ Department of Pathology and Poultry Diseases, College of \\ Veterinary Medicine, University of Mosul, Mosul, Iraq
}

\begin{tabular}{l} 
Article information \\
\hline Article history: \\
Received April 02, 2021 \\
Accepted September 08, 2021 \\
Available online December 20, 2021 \\
\hline Keywords: \\
Fluoxetine \\
Mice \\
Histopathology \\
Pregnancy \\
Lung \\
\hline
\end{tabular}

Correspondence:

S.S. Al-Mahmood

saevan981@yahoo.com

\begin{abstract}
The current study intends to look at the impact of the fluoxetine hydrochloride on specific tissues lung and pancreas of mature pregnant mice. The two doses used during the study were $45,75 \mathrm{mg} / \mathrm{kg}$ b.w. from the $7^{\text {th }}$ to the $17^{\text {th }}$ day of pregnancy. Experimental animals received fluoxetine orally at a dosage of $45 \mathrm{mg} / \mathrm{kg}$ b.w. The findings indicate variable pathologic changes in the lungs. At the dose of $75 \mathrm{mg} / \mathrm{kg}$ b.w. Hyperplasia of pneumocytes occurred. There were no detectible lesions in the pancreas at the dose of $45 \mathrm{mg} / \mathrm{kg}$ b.w. While at the dose of $75 \mathrm{mg} / \mathrm{kg} \mathrm{b.w}$. The severity of tissue lesions was seen. In conclusion, antidepressants may stimulate oxidative injury throughout the body's internal organs, particularly if taken at high doses during pregnancy. Consequently, these lesions significantly impact the health of both fetus and pregnant mice since the most common lesions were observed in the fetus, which causes abortion, which affects the health of pregnant mice.
\end{abstract}

DOI: 10.33899/ijvs.2021.129864.1695, CAuthors, 2022, College of Veterinary Medicine, University of Mosul.

This is an open access article under the CC BY 4.0 license (http://creativecommons.org/licenses/by/4.0/).

\section{Introduction}

Recently, the abuse of antidepressants such as fluoxetine has been a significant problem worldwide (1). Those drugs are often used in depression treatment. They may help depressed people to recover from their sickness, especially pregnant women who suffer from depression and emotional changes during pregnancy and after childbirth (2). One of the newest antidepressant drugs is Fluoxetine Hydrochloride (3). The drug's chemical formula is $\mathrm{C}_{17} \mathrm{H}_{18} \mathrm{~F}_{3} \mathrm{NO}$, and the scientific name of the drug is N-methyle-3-phenyle1-1-3 (4trifluoromethyl) phenoxylpropan-1-amine (4). Fluoxetine metabolism is done in the liver, and the drug is metabolized into norfluoxetine. Norfluoxtine is the drug's active metabolite, directly linked to medical and toxicological effects. The drug's active metabolite is directly related to medical and toxicological impact (5). About $80 \%$ of the drug is excreted with urine, and $57 \%$ with faeces (6). Moreover, the drug has a maternal effect. The severity of the impact depends on the dose and duration of exposure (7). Medical reports showed that the drug causes pulmonary hypertension syndrome in babies (8). Fluoxetine administration throughout gestation may cause a slow formation of the lungs (9). The drug caused an increase in mortality and altered the structure of phospholipids, hepatic changes when given to rats at a dosage of $10,50 \mathrm{mg} / \mathrm{kg}$ b.w. (10). The drug induces oxidative stress, which causes testicular damage, a significant decrease in the weight of reproductive organs, and affects the level of testosterone in the mice (11). Drug administration also causes injuries in the body's vital organs (12). Several studies referred to the drug's effect on carbohydrate metabolism and the function of beta cells (13).

The objective of this research project was to assess the impact of fluoxetine administration on the concentrations of $45,75 \mathrm{mg} / \mathrm{kg}$ of b.w. along with the maternal lung and pancreas of pregnant mice Mus musculus to evaluate the harmful effect of the drug on them. 


\section{Materials and methods}

In our investigation, twenty-one pregnant mice, aged three months, weighted $29 \pm 3$ gm, were used. Animals were taken from the College of Veterinary Medicine's animal house, Mosul University, Mosul, Iraq, and housed in the animals' house of the Biology Department, College of Education for Pure Science. Animals were caged in plastic cages, supported with free access to food and water, fed with a standard diet; the room temperature was $25^{\circ} \mathrm{C}$, the animals were exposed to a regular light-dark cycle (14). The drug used in the study is fluoxetine $20 \mathrm{mg}$ capsules produced by Bristol Laboratories Ltd., Bristol house, Unite 3, Canalside, Northbridge Road, United Kingdom. For the mating process, two females for one male were placed together in the same cage overnight. The next morning females with vaginal plugs were isolated in separate cages and kept together until the $7^{\text {th }}$ day of pregnancy. Animals' housing was done following the standard guidelines for the use and care of experimental animals.

The pregnant mice $(\mathrm{n}=21)$ were divided into three groups (each group consisted of 7 pregnant mice). Group I (control group): The pregnant mice $(\mathrm{n}=7)$ were administered with $0.2 \mathrm{ml}$ of distilled water orally from the day $7^{\text {th }}$ until the $17^{\text {th }}$ of pregnancy. Group II: The pregnant mice $(n=7)$ were administered orally with $45 \mathrm{mg} / \mathrm{kg}$ b.w. of fluoxetine drug from the $7^{\text {th }}$ day until the $17^{\text {th }}$ day of pregnancy. Group III: in this group, the pregnant mice $(n=7)$ were administered 75 $\mathrm{mg} / \mathrm{kg}$ b.w. of fluoxetine drug from day $7^{\text {th }}$ until day $17^{\text {th }}$ of pregnancy.

\section{Doses preparation}

The drug solution was prepared by dissolving each concentration in $5 \mathrm{ml}$ of distilled water (stock solution). The doses rates were between $0.13-0.15 \mathrm{ml}$, depending on the weight of pregnant mice. Those doses had been chosen depending on the LD50 of the drug, which is $100 \mathrm{mg} / \mathrm{kg}$ b.w. (15). The doses (drug solution) were prepared freshly every day during the experiments period.

\section{Histopathological preparation}

On the day $17^{\text {th }}$ of pregnancy, all pregnant mice were sacrificed and dissected, maternal lung and pancreas were dissected. Specimens were fixed in formalin $10 \%$ for 48 hours; later, they were washed with distilled water for two hours and processed with routine paraffin embedding technique (16). Sections were stained with hematoxylin and $\operatorname{eosin}(17)$.

\section{Results}

\section{Lung histopathology in adult pregnant mice}

Light microscope examination of the control lung section of the pregnant mice Mus musculus showed normal appearance of lung histology (Figure 1). Lung sections collected from pregnant mice performed $45 \mathrm{mg} / \mathrm{kg}$ b.w. of fluoxetine from the $7^{\text {th }}$ until the $17^{\text {th }}$ day of pregnancy showed satisfactory histopathological lesions represented with serofibrinous oedema in the air space of alveoli and infiltration of inflammatory cells as well as enlarged airspace and mild thickening of alveolar septa (Figure 2) as well as degeneration of the pulmonary lining epithelium cells and congestion (Figure 3). While the examination of the lung sections obtained from pregnant mice given $75 \mathrm{mg} / \mathrm{kg}$ b.w. of fluoxetine drug orally for the same period above showed that previous lesions were increased, especially the congestion of blood vessel (Figure 4), as well as hyperplasia of the lung epithelium tissue, was observed (Figure 5).

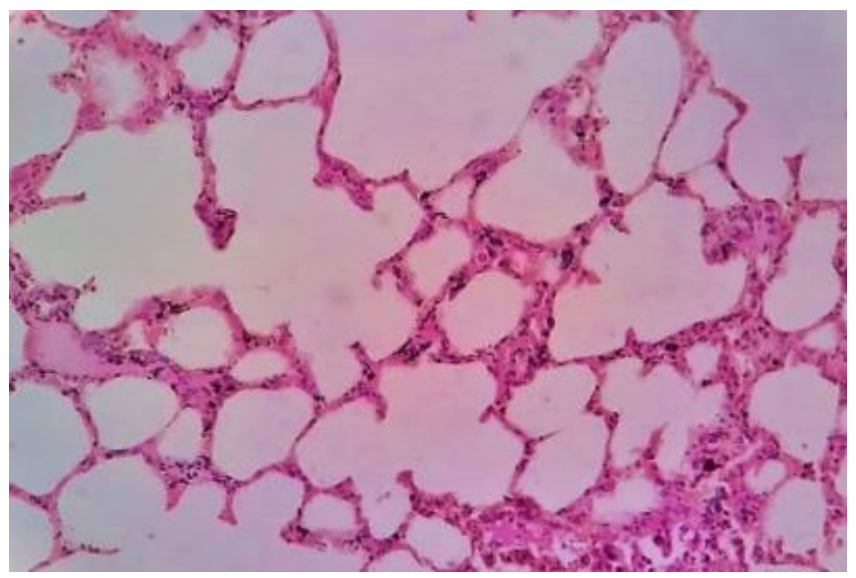

Figure 1: A cross-section photomicrograph of the control pregnant mouse Mus musculus lung showing normal lung histology. (10x. H\&E).

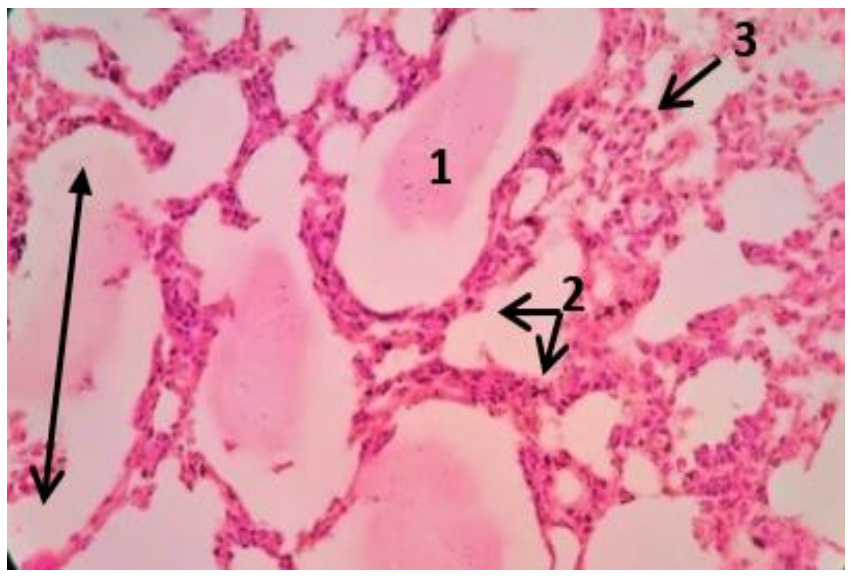

Figure 2: A cross-section photomicrograph of the lung of pregnant mouse Mus musculus treated with fluoxetine drug at the dose of $45 \mathrm{mg} / \mathrm{kg}$ of b.w. from the $7^{\text {th }}$ day until $17^{\text {th }}$ day of pregnancy showing serofibrinous oedema (1), enlargement of pulmonary air space (black arrow), mild thickening of alveolar septa (2), infiltration of inflammatory cells (3). (400x. H\&E). 


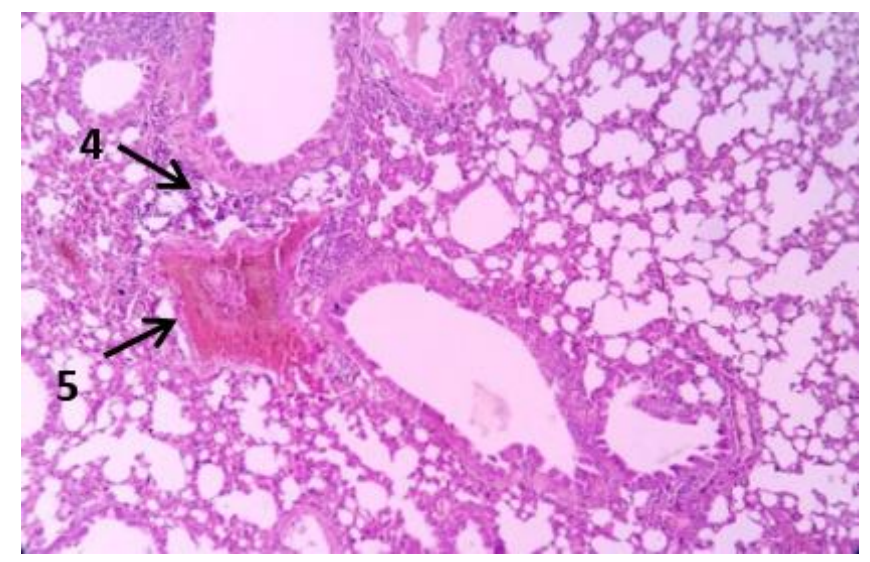

Figure 3: A cross-section photomicrograph of the lung of the pregnant mouse Mus musculus treated with fluoxetine drug at the dose of $45 \mathrm{mg} / \mathrm{kg}$ of b.w. from the 7th day until the 17th day of pregnancy showing degeneration of lung epithelium cells (4) and congestion (5). (10x. H\&E).

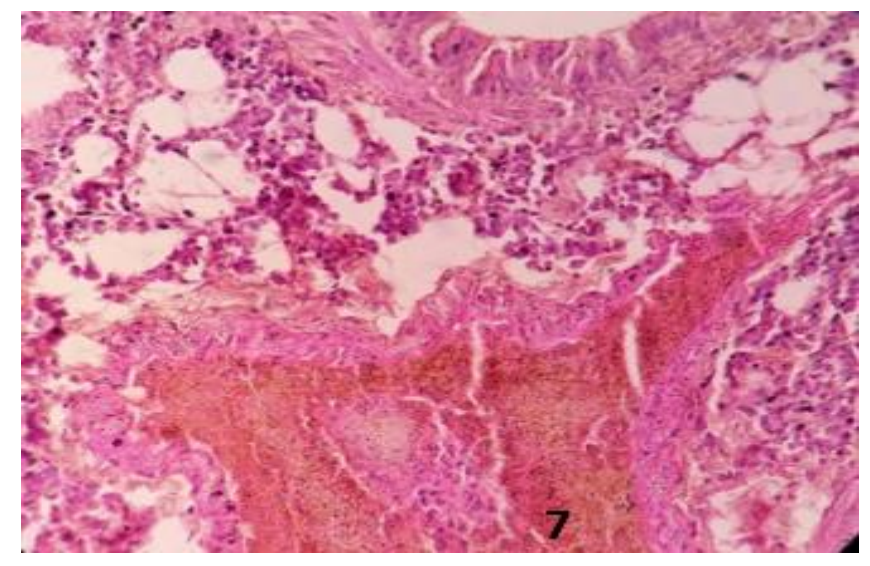

Figure 4: A cross-section photomicrograph of the lung of the pregnant mouse Mus musculus treated with fluoxetine drug at the dose of $75 \mathrm{mg} / \mathrm{kg}$ of b.w. from day 7 to day 17 during pregnancy shows an increase in the congestion of blood vessels (7). (10x. H\&E).

\section{Histopathological observations of the pancreas of pregnant mice}

Light microscope examination of the control pancreas of pregnant mice Mus musculus showed normal lobules and normal pancreatic cells (Figure 6). Pancreas sections were obtained from pregnant mice given $45 \mathrm{mg} / \mathrm{kg}$ b.w. of fluoxetine drug orally from the $7^{\text {th }}$ until the $17^{\text {th }}$ day of pregnancy. The histological changes and the dose increase were increased, so sections of the pancreas obtained from the pregnant mice given $75 \mathrm{mg} / \mathrm{kg}$ b.w. of fluoxetine drug orally for the same period above revealed vacuolation of the pancreatic cells (Figure 7). Hypertrophy of some of them, congestion of the blood vessel, and the increase of eosinophilia of some pancreatic cells cytoplasm (Figure 8).

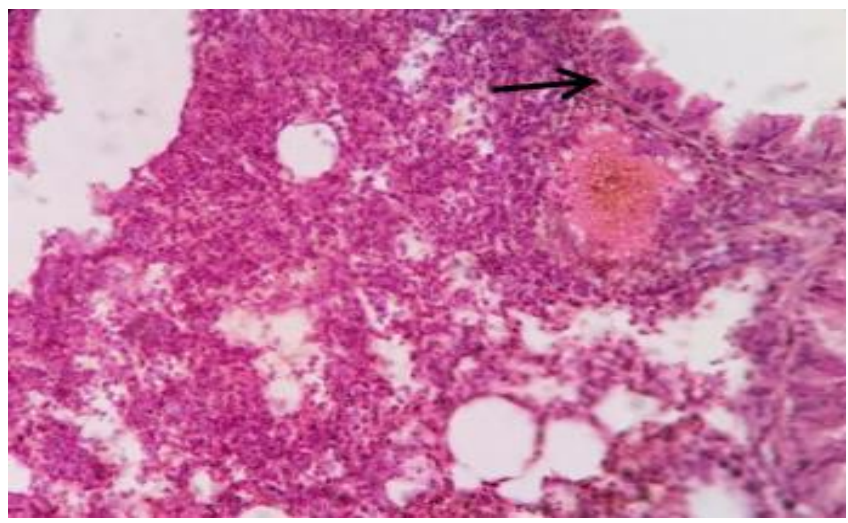

Figure 5. A cross-section photomicrograph of the lung of the pregnant mouse Mus musculus treated with fluoxetine drug at the dose of $75 \mathrm{mg} / \mathrm{kg}$ of b.w from day 7 to day 17 during pregnancy, showing hyperplasia of tracheal epithelium cells (black arrows). (10x. H\&E).

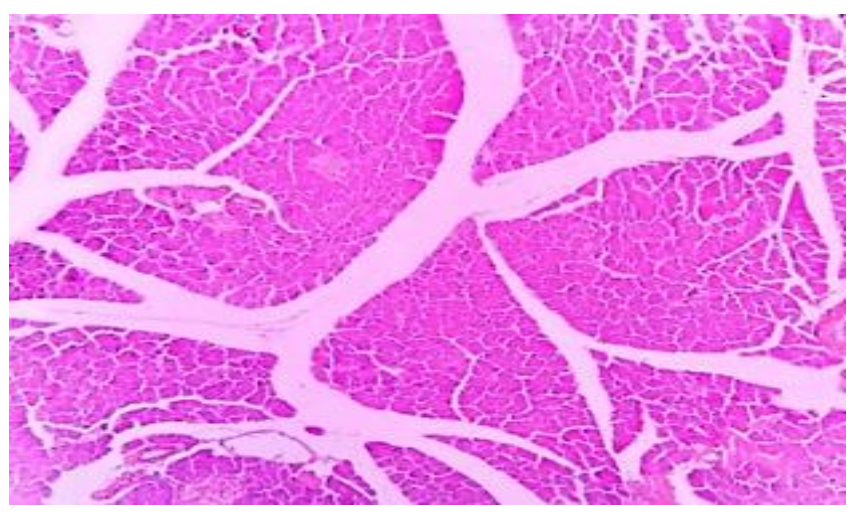

Figure 6: Cross-section photomicrograph of the pregnant mouse Mus musculus's control pancreas shows normal pancreatic lobules and normal pancreatic cells. (10x. H\&E).

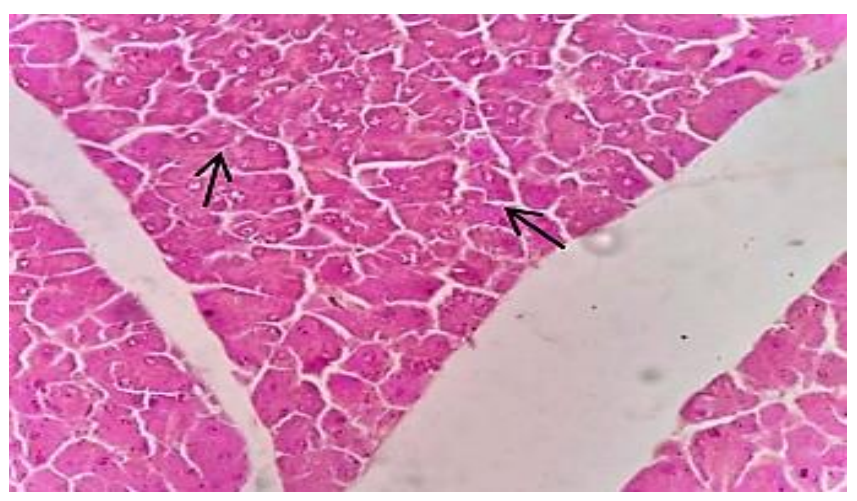

Figure 7: Cross-section photomicrograph of the pancreas of pregnant mice Mus musculus treated with fluoxetine drug at the dose of $75 \mathrm{mg} / \mathrm{kg}$ of b.w. from day 7 to day 17 during pregnancy showing vacuolation of pancreatic cells (black arrows). (10x. H\&E). 


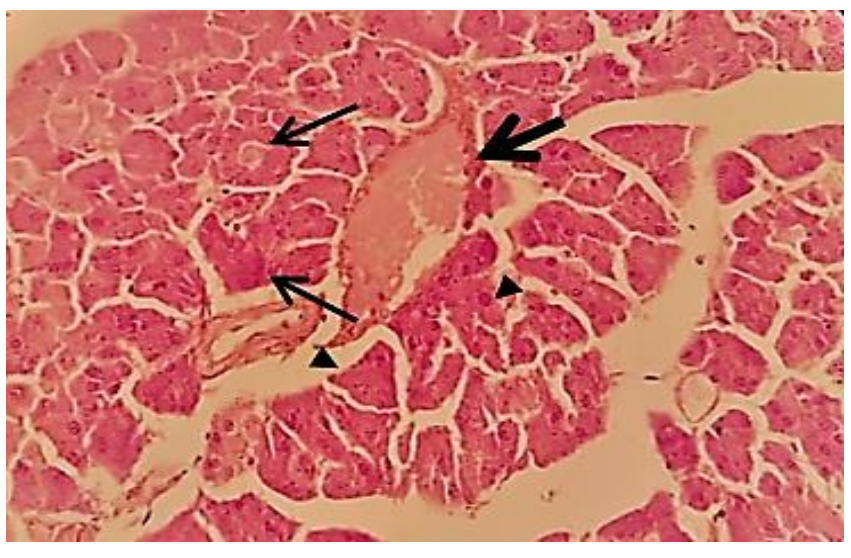

Figure 8: Cross-section photomicrograph of the pancreas of pregnant mouse Mus musculus that treated with fluoxetine drug at the dose of $75 \mathrm{mg} / \mathrm{kg}$ of b.w. from day 7 to day 17 during pregnancy showing hypertrophy of some pancreatic cells (thin black arrow), eosinophils of some pancreatic cells cytoplasm (black arrows heads), congestion of the blood vessel (thick black arrow). (400x. H\&E).

\section{Discussion}

In our study, the Macroscopical examination of the lung of pregnant mice administrated orally with $45,75 \mathrm{mg} / \mathrm{kg}$ b.w. of fluoxetine showed serofibrinous oedema in the alveolar air space, degeneration of the alveolar lining epithelium, infiltration of inflammatory cells, congestion, and hyperplasia. The lesions were increased as well, as the dose increased. Those lesions were similar to those reported by $(9,12,18)$. This study's findings correspond with those of $(19)$ as all of them confirmed that taking fluoxetine during pregnancy causes hyperplasia of alveolar septa. The results of this study may be directly attributable to that inflammatory response induced by fluoxetine. This induction may be linked to fluoxetine impairing the phospholipids metabolism, which involves pathological lesions such as inflammatory cells infiltration and degeneration (20). on the other hand, it may be due to the use of fluoxetine during pregnancy, which may alter some metabolic pathways and increase in the levels of oxidative stress, which in turn cause formation of destructive free radicals, those molecules disturb and destroy the functions and structure of the lung cells (21).

The findings from the current study had shown histopathological lesions in pregnant mice's pancreas that were treated with fluoxetine at $45,75 \mathrm{mg} / \mathrm{kg}$ b.w. for the preceding period, so the most noticeable lesions at the 75 $\mathrm{mg} / \mathrm{kg}$ dose were blood vessel congestion, vacuolation of pancreatic cytoplasm and hypertrophy of some pancreatic cells. Study findings did not correspond with the findings of (22). At the same time, the present study results were similar to the finding of (23). The results were somewhat similar to the finding of (24). The finding of the current study may be due to the, that using fluoxetine for depression treatment during pregnancy may involve inducing cytotoxic mechanism in the body cells, which in turn increase the production of free radical oxygen species that destroy cellular mitochondria, proteins, lipids, and nucleic acids (25).

\section{Conclusion}

In conclusion, antidepressants may stimulate oxidative injury throughout the body's internal organs, particularly if taken at high doses during pregnancy. Consequently, they should always be used caution to avoid adversely.

\section{Acknowledgements}

The authors would thank the University of Mosul to support the current study.

\section{Conflict of interest}

No conflict of interest.

\section{References}

1. Hubbard JR, Martin PR. Substance abuse in the mentally and physically disabled. New York: CRC Press; 2001. 26 p.

2. Fleschler R, Peskin MF. Selective serotonin reuptake inhibitors (SSRIs) in Pregnancy: A review. MCN Am J Matern Child Nurs. 2008;33:355361. DOI: $10.1007 / \mathrm{s} 40263-016-0338-3$

3. Atamura AC, Moro AR, Perudanni M. Clinical pharmacokinetics of fluoxetine. Clin Pharm. 1994;26(3):201-214. DOI: 10.2165/00003088199426030-00004

4. Myers RL. The most important chemical compounds: A reference guide. $1^{\text {st }}$ ed. Westport: Greenwood Press; 2007. 128 p.

5. Ozden H, Bildirici KI, Ustüner D, Ustüner C, Cengiz BP, Tulay A, Yilmaz V. Histopathologic examination of rat liver after experimental application of fluoxetine. Türkiye Ekopatoloji Dergisi. 2005;11 9-15. [available at]

6. Wiliams K, Brignell A, Randall M, Silone N, Hazell P. Selective serotonin reuptake inhibitors (SSIRs) for autism spectrum disorders (ASD). Sys Rev. 2013;8(8):46-77. DOI: 10.1002/14651858.CD004677.pub3

7. Berard A. Antidepressant use during pregnancy and the risk of major congestion malformations in a cohort of depressed pregnant women: An updated analysis of the Quebec Pregnancy Cohort. BMJ. 2017;7:1321. DOI: $10.1136 /$ bmjopen-2016-013372

8. Fornaro E, Li D, Pan J, Belik J. Prenatal exposure to fluoxetine induces fetal pulmonary hypertension in the rat. Am J Res Crit Care Med. 2007;76:1035-1040. DOI: 10.1164/rccm.200701-163OC

9. Ghavamabadi RT, Taghipour Z, Hassanipour M, Shariati M. Effect of maternal fluoxetine exposure on lung heart and kidney development in rat neonates. Iran Basic Med Sci. 2018;21(4):417-421. DOI: 10.22038/JJBMS.2018.27203.6650

10. Bendele RA, Adams ER, Hoffman WP, Gries CL, Morton DM. Carcinogenicity studies of fluoxetine hydrochloride in rats and mice. Vet Rec. 1992;34(4):23-29. [available at]

11. Hajizadeh Z, Mehranjani M.S, Najafi G, Shariatzadeh SA, Jalali AS. Black grape seed extract modulates fluoxetine-induced oxidative stress and cytotoxicity in the mouse testis. Jundishapur J Nat Pharm Prod. 2016;11(2):27-32. DOI: 10.17795/jjnpp-27512 
12. Rosenberg T, Lattimer_R, Montgomery P, Wiens C, Levy L. The relationship of SSRI and SNRI usage with interstitial lung disease and bronchiectasis in an elderly population: a case-control study. Clin Interv Aging. 2017;12:19-20. DOI: 10.2147/CIA.S144263

13. De Long NE, Hyslop JR, Raha S, Hardy DB, Holloway AC. Fluoxetine-induced pancreatic beta-cell dysfunction: New insight into the benefits of folic acid in the treatment of depression. J Affect Dis. 2014;12:90-101. DOI: 10.1016/j.jad.2014.04.063

14. Czeizel AE, Puho EH, Acs N, Banhidy F. Use of specified critical periods of different congenital abnormalities instead of the firsttrimester concept. Res Clin Mol Teratol. 2008;82(3):139-146. DOI: 10.1002/bdra.20431

15. Suchard JR. Fluoxetine over dose-induced seizure. West J Med. 2008;9(3):154-156. [available at]

16. A-Hajj HA. Optical laboratory preparation. $1^{\text {st }}$ ed. Jordan: Dar AlMassera Press; 2010. 34-69 p.

17. Suvarna S. K, Layton C, Bancroft JD. Theory and practice of histological techniques. $7^{\text {th }}$ ed. London: Churchill Livingstone press; 2013. $173-187 \mathrm{p}$

18. Gonzalez RJ, Zande DS, Ros PR. Fluoxetine hydrochloride (Prozac)induced pulmonary disease. Chest. 1995;107(6):1763-5. DOI: 10.1378/chest.107.6.1763

19. Dauger S, Ferkdadji L, Saumon G, Vardon G, Peuchmaur M, Gaultier C, Gallego J. Neonatal exposure to $65 \%$ oxygen durably impairs lung architecture and breathing pattern in adult mice. Chest. 2003;123(3):530-538. DOI: 10.1378/chest.123.2.530

20. Davis EA, Oohony MS. Adverse drug reaction in special population the elderly: ADRs in the elderly. British J Clin Pharmacol. 2015;1(2):101110. DOI: $10.1111 / \mathrm{bcp} .12596$

21. Allen JN. Drug-induced eosinophilic lung disease. Clin Chest Med. 2004;25(1):77-88. DOI: 10.1016/S0272-5231(03)00141-2

22. Mekahli D, Bultynck G, Parys JB, De Smedt H, Missiaen L. Endoplasmic-reticulum calcium depletion and disease. Perspect Biol. 2011;3:17. DOI: 10.1101/cshperspect.a004317

23. Chang HY, Chen SL, Shen MR, Kung ML, Chuang LM, Chen YW. Selective serotonin reuptake inhibitor fluoxetine impairs E-cadherinmediated cell adhesion and alters calcium homeostasis in pancreatic beta cells. Sci Report. 2017;(1):3515. DOI: 10.1038/s41598-017$\underline{03747-0}$

24. Youssef S. Effect of fluoxetine on the pancreas of adult male Albino rats and the possible protective role of omega-3: light and possible electron microscope study. Inter Develop Anat. 2017;(3):45-56. [available at]

25. Steinberg WM, Nauck MA, Zinman B, Daniels GH, Bergenstal RM, Mann JF. Leader 3-lipase and amylase activity in subjects with type 2 diabetes: baseline data from over 9000 subjects in the leader trial. Pancreas. 2014;43:1223-1231. DOI: 10.1097/MPA.000000000000229

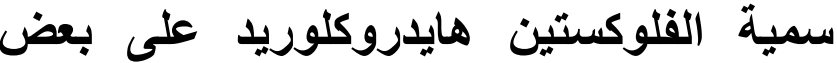

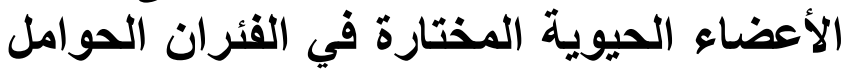 Mus musculus}

\author{
بيداء عبدالعزيز محمد' و سيقان سعد المحمود'

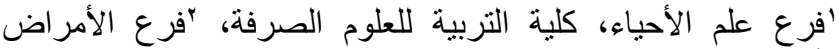 \\ و أمراض الدواجن، كلية الطب البيطري، جامعة الموصل، الموصل، \\ العراق \\ الخلاصة
}

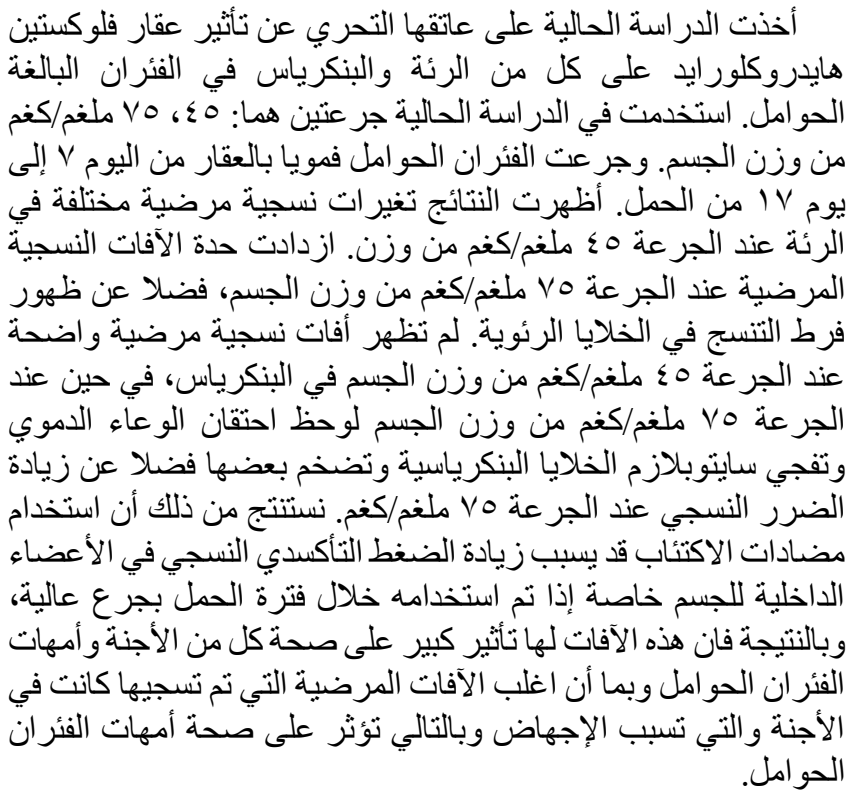

